\title{
KEWENANGAN PENYIDIK KEPOLISIAN DALAM MELAKUKAN PENYIDIKAN TINDAK PIDANA KORUPSI
}

\author{
I Putu Edi Rusmana, I Made Minggu Widyantara, Luh Putu Suryani \\ Fakultas Hukum, Universitas Warmadewa, Denpasar-Bali, Indonesia \\ iputuedirusmana94@gmail.com, mademinggu21@gmail.com, putusuryani099@gmail.com
}

\begin{abstract}
Abstrak
Berbagai peraturan perundang-undangan yang diciptakan sebagai pengganti aturan sebelumnya, belum menjamin keberhasilan dalam pemberantasan tindak pidana korupsi di Indonesia. Adanya beberapa undangundang yang mengatur mengenai wewenang serta kewajiban setiap aparat penegak hukum seperti Polisi, Jaksa, Hakim dan KPK sehingga menimbulkan kekaburan kewenangannya atau terjadi tumpang tindih kewenangan yang diberikan oleh negara menimbulkan persepsi yang keliru misalnya polisi sebagai penyidik merasa berwenang melakukan penyidikan tindak pidana korupsi selain jaksa maupun KPK. Adapun tujuan penelitian ini guna menganalisa pengaturan kewenangan penyidik kepolisian dalam melakukan penyidikan terhadap kasus tindak pidana korupsi serta kendala-kendala apakah yang dihadapi oleh penyidik kepolisian dalam melakukan penyidikan terhadap tindak pidana korupsi. Dalam penelitian ini merupakan tipe penelitian hukum normatif dengan pendekatan konseptual dan pendekatan perundang-undangan. Sumber hukum yang digunakan yaitu bahan hukum sekunder. Metode pengumpulan sumber bahan hukum yang digunakan dalam penelitian ini adalah pengkategorian sumber bahan hukum. Bahan-bahan hukum yang telah terkumpul, kemudian pada saat pembahasan akan diolah serta dianalisis dengan interpretasi hukum dan argumentasi hukum, deduktif kemudian dituangkan secara deskriptif. Hasil penelitian menunjukkan bahwa belum adanya kerjasama dalam bentuk peraturan perundang-undangan antara penyidik Kepolisian dengan pihak penegak hukum lainnya seperti Kejaksaan dan KPK, maka perlu segera dibentuk undang-undang yang mengatur secara jelas dan rinci tentang wewenang, kerjasama dan koordinasi dalam melakukan penyidikan tindak pidana korupsi, hal ini perlu dilakukan agar menjadi lebih efektif dan dapat terwujud.
\end{abstract}

Kata Kunci: Kendala yang dihadapi Penyidik, Tindak Pidana Korupsi, Wewenang Penyidik Kepolisian

\begin{abstract}
Various laws and regulations that were created as a substitute for the previous rules, have not guaranteed success in eradicating corruption in Indonesia. The existence of several laws that regulate the authority and obligations of each law enforcement officer such as the Police, Prosecutors, Judges and the KPK so that it creates a blurring of their authority or there is an overlap of authority granted by the state creates a wrong perception, for example, the police as investigators feel they are authorized to carry out criminal investigations. corruption in addition to prosecutors and the KPK. The purpose of this study is to analyze the regulation of the authority of police investigators in conducting investigations into cases of criminal acts of corruption and what obstacles are faced by police investigators in conducting investigations into criminal acts of corruption. This research is a normative legal research type with a conceptual approach and a statutory approach. The legal sources used are secondary legal materials. The method of collecting legal material sources used in this study is the categorization of legal material sources. The legal materials that have been collected, then during the discussion will be processed and analyzed with legal interpretations and legal arguments, deductively then poured descriptively. The results of the study indicate that there is no cooperation in the form of legislation between police investigators and other law enforcement parties such as the Prosecutor's Office and the KPK, it is necessary to immediately establish a law that regulates clearly and in detail about the authority, cooperation and coordination in conducting criminal investigations. corruption, this needs to be done in order to be more effective and can be realized.
\end{abstract}

Keywords: Obstacles faced by Investigators, Corruption Crimes, Authority of Police Investigators

\section{PENDAHULUAN}

Indonesia sebagai salah satu negara berkembang pasti mempunyai permasalahan dalam perkembangan negaranya. Negara Republik Indonesia merupakan negara hukum, seperti yang sudah ditegaskan dalam Pasal 1 ayat (3) hasil amandemen Undang-undang Dasar Negara RI Tahun 1945. 
Guna mewujudkan prinsip-prinsip negara hukum, diperlukanlah norma-norma hukum, peraturan perundang-undangan, aparatur pengemban dan penegak hukum yang profesional, berintegritas dan disiplin agar dapat mendukung terjadinya hukum serta perilaku yang baik di masyarakat. Oleh karena itu, hukum serta penegak hukum adalah sebagian aspek penegakan hukum yang tidak dapat diabaikan, bila diabaikan akan menimbulkan tidak tercapainya penegakan hukum yang diharapkan (Soekanto, 1983).

Tindak pidana korupsi termasuk golongan kejahatan luar biasa (extraordinary crime). Hal tersebut sudah ditegas dalam Konvensional International Persatuan Bangsa-Bangsa (PBB) di Venna. Pada pertemuan tersebut melahirkan beberapa gagasan untuk menerbitkan deretan-deretan UndangUndang Korupsi, bahkan membentuk Komisi Pemberantasan Korupsi yang diberikan kewenangan yang luas untuk menindak perkara korupsi (Mas, 2014). Adanya beberapa kepentingan tarik menarik antara Jaksa dan Kepolisian untuk tugas penyidikan dalam tindak pidana korupsi. Pihak Kejaksaan menggunakan dasar hukum Undang-Undang No. 3 Tahun 1971 dan diganti dengan Undang-undang No. 31 Tahun 1999 dan telah diubah menjadi Undang-undang No. 20 tahun 2001, sedangkan pihak Kepolisian menggunakan dasar hukum Undang-undang No. 2 Tahun 2002. Silih bergantinya peraturan perundang-undangan yang diciptakan belum juga menghasilkan keberhasilan dalam pemberantasan tindak pidana korupsi di Indonesia. Dengan adanya beberapa institusi penegak hukum di Indonesia menimbulkan kekaburan kewenangan atau menjadi tumpang tindih kewenangan yang diberikan kepadanya oleh negara, sehingga menimbulkan persepsi yang keliru. Adanya kerancuan dan tumpang tindih kewenangan tersebut menimbulkan kesan yang cenderung apriori dan seolah-olah menjadi rebutan untuk menangani penyidikan tindak pidana korupsi sebagai lahan basah, apalagi tindak pidana korupsi menjadi pusat perhatian masyarakat luas dan menjadi prioritas utama dalam penegakan hukum pidana pada khususnya.

Walaupun sudah adanya lembaga KPK yang secara khusus menyidik perkara korupsi tetapi tidak berarti penyidik kepolisian tidak berhak mengusut kasus korupsi, karena kepolisian juga memiliki wewenang untuk melakukan penyidikan tindak pidana korupsi. Kepolisian juga berwenang untuk melakukan penyidikan tindak pidana korupsi, karena hal tersebut juga bagian dari tugas pokok kepolisian untuk menjaga keamanan dan ketertiban di masyarakat. Kepolisian diberikan peranan oleh KUHAP dalam penyidikan dan penyelidikan sehingga secara umum diberi kewenangan untuk melakukkan penyidikan dan penyelidikan terhadap semua jenis tindak pidana, hal tersebut diatur dalam Undang-undang No. 2 Tahun 2002 tentang Kepolisian Negara Republik Indonesia, termasuk untuk melakukan penyidikan tindak pidana korupsi sebagaimana dirumuskan dalam ketentuan Pasal 14 ayat 1 huruf $g$ tersebut.

Menurut Mursalim (2017) Kewenangan Penyidik Polri sebagai penegak hukum dalam tindak pidana yaitu melakukan penangkapan terhadap seseorang yang diduga melakukan tindak pidana, melakukan penahanan kepada tersangka apabila sudah cukup bukti untuk kepentingan penyidikan, melakukan pemeriksaan terhadap tersangka untuk mendapatkan suatu keterangan terhadap tindak pidana yang diiakukan seseorang. Berkaitan dengan tindak pidana korupsi terdapat beberapa lembaga penegak hukum yang diberikan kewenangan penyidikan, yakni kewenangan penyidikan yang diberikan kepada Kepolisian sebagaimana diatur dalam Pasal 14 ayat (1) huruf g Undang-Undang No. 2 Tahun 2002 tentang Kepolisian Negara Republik Indonesia (UU Kepolisian) (Assa, 2017). Adapun menurut Siahaan et al., (2019) pengaturan peran kepolisian dalam penyidikan tindak pidana korupsi ditemukan dalam Undang-undang No. 8 Tahun 1981 Tentang KUHAP, Undang-Undang No. 31 Tahun 1999 Tentang Tindak Pidana Korupsi sebagaimana telah diubah dengan Undang-Undang No. 20 Tahun 2001 serta Undang-undang No. 2 Tahun 2002 Tentang Kepolisian Negara Republik Indonesia, dimana dari kesemua pengaturan tersebut menjelaskan bahwa penyidik termasuk dalam kasus tindak pidana korupsi adalah Pejabat Polisi Negara Republik Indonesia.

Berdasarkan pemaparan diatas, maka didapat suatu tujuan penelitian yaitu menganalisa pengaturan kewenangan penyidik kepolisian dalam melakukan penyidikan terhadap kasus tindak pidana korupsi serta kendala-kendala apakah yang dihadapi oleh penyidik kepolisian dalam melakukan penyidikan terhadap tindak pidana korupsi.

\section{METODE PENELITIAN}

Dalam penulisan penelitian ini, tipe penelitian yang dipergunakan adalah tipe penelitian hukum normatif, yaitu penelitian hukum yang dilakukan dengan cara meneliti bahan pustaka/data sekunder. 
Sedangkan pendekatan masalah yang digunakan adalah pendekatan konseptual dan pendekatan perundang-undangan, Metode pengumpulan sumber bahan hukum yang digunakan dalam penelitian ini adalah pengkategorian sumber bahan hukum Undang-Undang Dasar (UUD) Negara Republik Indonesia 1945, Undang-undang No. 1 Tahun 1946 Tentang Kitab Undang- Undang Hukum Pidana (KUHP), Undang-Undang Nomor 31 Tahun 1999 Tentang Perubahan Kedua Atas Undang-Undang Nomor 20 Tahun 2001, Undang-Undang Nomor 19 Tahun 2019 Tentang Perubahan Kedua Atas Undang-undang Nomor 30 Tahun 2002 Tentang Komisi Pemberantasan Korupsi (KPK), UndangUndang No. 2 Tahun 2002 tentang Kepolisian Negara Republik Indonesia, Undang-undang No. 8 Tahun 1981 tentang Kitab Undang-Undang Hukum Acara Pidana (KUHAP) dan Undang-Undang No 16 Tahun 2004 tentang Kejaksaan. Selanjutnya dilakukan metode pencatatan, meringkas, dan mengulas sesuai dengan pokok masalah. Bahan-bahan hukum yang telah terkumpul, kemudian pada saat pembahasan akan diolah serta dianalisis dengan interpretasi hukum dan argumentasi hukum, deduktif, dan bahan hukum yang telah diperoleh suatu kebenaran untuk berusaha memahami kebenaran tersebut, kemudian dituangkan secara deskriptif.

\section{HASIL DAN PEMBAHASAN}

\section{Pengaturan Kewenangan Penyidik Kepolisian dalam Melakukan Penyidikan Terhadap Kasus Tindak Pidana Korupsi}

Korupsi berasal dari bahasa latin; Corrupti atau Corruptus yang berarti kebejatan, kebusukan, tidak bermoral, dapat disuap, tidak jujur, penyimpangan dari suatu kesucian, kata-kata yang menghina atau memfitnah. Korupsi mencakup tentang penggelapan dalam istilah tersebut (Hamzah, 1984). Istilah korupsi berarti pengrusakan (bederving), atau pelanggaran (schending) dan dalam hal luas memiliki arti menyalahgunakan (misbruik) (H, 2000). Adanya beberapa faktor yang mempengaruhi terjadinya korupsi di Indonesia yakni yang pertama adalah faktor politik yang berkaitan dengan kekuasaan, yang kedua faktor yuridis yang berarti berkaitan dengan hukum dan yang ketiga adalah factor budaya yang merupakan peninggalan pandangan feodal yang menjadi benturan kesetiaan antara keluarga dan kewajiban terhadap negara.

Unsur-unsur korupsi diatur pada Undang-undang Nomor 31 Tahun 1999 tentang Pemberantasan Tindak Pidana Korupsi. Adapun unsur-unsurnya antara lain, yang pertama yakni pelaku (subjek). Yang kedua yakni melawan hukum baik formil maupun materiil. Yang ketiga adalah memperkaya diri sendiri, orang lain atau korporasi. Dan yang keempat adalah dapat merugikan keuangan atau perekonomian negara. Seluruh unsur-unsur tersebut diatur pada Pasal 2 ayat (1) dan dapat dihubungkan dengan Pasal 20 ayat (1) sampai (7). Dari sudut perundang-undangan, pemberantasan tindak pidana korupsi dikeluarkan Peraturan Penguasa Militer untuk kekuasaan Angkatan Darat No. PRT/DM06/1957 tentang Pemberantasan Korupsi yang kemudian kurang efektif dilengkapi dengan Peraturan Militer No. PRT/PMD08/1957 yang mengatur tentang penguasa militer yang mendapatkan harta dan kekayaan secara mendadak dan mencurigakan. Diundangkannya Peraturan Penguasa Perang Pusat Angkatan Darat No. PRT/Peperpu/013/1958 tentang pengusutan, penuntutan, dan pemberantasan perbuatan korupsi pidana dan pemilikan harta benda.

Berlakunya Undang-undang No. 3 Tahun 1971 tentang Pemberantasan Tindak Pidana Korupsi dianggap kurang mampu memberantas korupsi di Indonesia. Bahkan berdasarkan Undang Undang Dasar 1945 pada Pasal 23 ayat (5) telah ada Badan Pemeriksa Keuangan (BPK). Dan pada masa Orde Baru, Presiden saat itu membentuk lembaga pengawas yang bertindak sebagai pemeriksa, yakni Badan Pengawas Keuangan dan Pembangunan (BPKP). Adanya tumpang tindih/duplikasi atau konflik norma antara Komisi Pemberantasan Korupsi dengan penegak hukum lainnya dalam pemberantasan tindak pidana korupsi. Undang-undang No. 8 Tahun 1981 tentang Hukum Acara Pidana yang telah mengatur fungsi, tugas, dan wewenang penegak hukum dalam penanggulangan kejahatan termasuk pemberantasan tindak pidana korupsi, masih ditambah lagi dengan dibentuknya lembaga baru yakni Komisi Pemberantasan Korupsi yang mempunyai wewenang independen dalam pemberantasan tindak pidana korupsi, melebihi wewenang Polisi dan Jaksa Penuntut Umum dalam penyelidikan, penyidikan dan penuntutan yang menjadi tugas polisi dan jaksa penuntut umum sesuai KUHAP. Dalam kenyataan semakin banyaknya lembaga yang berwenang dalam melakukan pemberantasan tindak pidana korupsi tersebut dapat diselesaikan secara optimal, namun menimbulkan efek psikologis di kalangan penegak hukum. 
Dalam Undang-Undang No. 8 Tahun 1981 tentang Kitab Undang-Undang Hukum Acara Pidana, penyidik Pegawai Negeri Sipil yang merupakan pembantu Kepolisian Negara Republik Indonesia. Sesuai Pasal 3 ayat (1) b Undang-Undang No. 2 Tahun 2002 tentang Kepolisian Negara Republik Indonesia harus melaporkan dalam melakukan tugasnya kepada Polri, akan tetapi Komisi Pemberantasan Korupsi justru melakukan koordinasi, pengawasan, dan supervisi terhadap penegak hukum termasuk kepada Polri, Kejaksaan, Pengadilan dalam upaya penegakan hukum.

Tugas pokok dan kewenangan Kepolisian Negara Republik Indonesia diatur dalam BAB II Pasal 13 Undang-Undang No. 2 Tahun 2002 tentang Kepolisian Negara Republik Indonesia. Dalam Pasal 14 ayat (1) menjelaskan tugas dari Kepolisian Negara Republik sebagaimana yang telah dimaksud dalam Pasal 13 tersebut.Kepolisian Negara Republik Indonesia memiliki wewenang dan dalam melaksanakan tugas- tugasnya diatur dalam Pasal 14 hingga Pasal 16 Undang-Undang No. 2 Tahun 2002 tentang Kepolisian Negara Republik Indonesia.

Berdasarkan uraian tugas dan kewenangan kepolisian dapat menjadi dalam tugas preventif dan tugas represif. Fungsi preventif untuk pencegahan dan perlindungan terhadap hal-hal yang mengancam dan mengganggu ketertiban umum. Sedangkan fungsi represif berarti polisi wajib menyidik perkara-perkara pidana, menangkap, dan menyerahkan pelakunya untuk penyidikan dan untuk penghukuman. Sebelum dibentuknya KPK, Polri diberi kewenangan untuk melakukan penyidikan dan penyelidikan terhadap semua tindak pidana, yang diatur ataupun di luar KUHP, yang termasuk terhadap tindak pidana korupsi. Terlebih lagi kepolisian juga dikategorikan sebagai penyidik seluruh tindak pidana yang diatur dalam Pasal 14 huruf g Undang-Undang No. 2 Tahun 2002 tentang Kepolisian Negara Republik Indonesia. Ruang lingkup penyidikan dalam melakukan penyidikan tindak pidana korupsi yakni penangkapan, penahanan, penggeledahan, penyitaan. Hal tersebut diatur dalam Undang-Undang No. 8 Tahun 1981 tentang Kitab Undang-Undang Hukum Acara Pidana.

\section{Kendala-Kendala yang dihadapi oleh Penyidik Kepolisian dalam Melakukan Penyidikan Terhadap Tindak Pidana Korupsi}

Penyidikan tindak pidana korupsi dilakukan berlandaskan hukum acara pidana yang berlaku di Indonesia yakni Undang-undang Nomor 8 Tahun 1981 tentang Kitab Undang-Undang Hukum Acara Pidana (KUHAP). Sedangkan Pejabat Negara Republik Indonesia atau Pejabat Pegawai Negeri Sipil tertentu adalah penyidik yang diberi wewenang khusus untuk melakukan penyidikan sesuai UndangUndang. Berdasarkan KUHAP, wewenang Kepolisian dalam melakukan tugas penyidikan dan penyelidikan diatur dalam Pasal 1 butir 5 KUHAP. Di Dalam KUHAP tidak ada satu pasal yang menyebutkan bahwa polisi adalah penyidik tunggal, namun secara implisit yang kuat untuk ikut melakukan penyidikan dan penyelidikan dalam kasus korupsi yang kemudian melahirkan Divisi Tipikor (Hatta, 2014).

Dalam penyidikan sistem peradilan pidana, prosedur penyidikan yang dilakukan oleh Kepolisian dalam tindak pidana korupsi tetap mengacu pada UU No. 8 Tahun 1981 tentang Kitab Undang-Undang Hukum Acara Pidana (KUHAP). Walaupun secara teknis tindakan penyidikan sudah diatur dalam KUHAP, ada beberapa kendala yang dihadapi kepolisian dalam menangani kasus tindak pidana korupsi. Kendala tersebut menjadi suatu tugas yang harus dipenuhi agar dalam menangani kasus tindak pidana korupsi tidak mendapatkan kendala-kendala dalam melakukan penyidikan terhadap tindak pidana korupsi.

Ada beberapa kendala yang harus dihadapi kepolisian dalam melakukan penyidikan tindak pidana korupsi, hal tersebut dibagi menjadi dua kendala yaitu kendala yuridis dan kendala teknis. Kendala yang pertama yakni Kendala Yuridis yang dibagi menjadi dua bagian, yang pertama yakni tumpang tindihnya kewenangan penyidikan tindak pidana korupsi yang berarti terjadinya tumpang tindih antara beberapa instansi (Kepolisian, Jaksa dan KPK) yang berwenang melakukan penyidikan tindak pidana korupsi. Hal tersebut jelas menjadi kendala untuk kepolisian dalam melakukan penyidikan karena perbedaan peraturan yang masing-masing memiliki aturan yang berbeda dalam melakukan penyidikan. Yang kedua adalah transaksi keuangan dilakukan secara tunai tanpa melalui perbankan yang berarti sulit untuk menemukan bukti-bukti apabila transaksi dilakukan secara tunai, karena sebagian besar tidak ada barang bukti dan saksi yang menyaksikan transaksi tersebut, hal tersebut sulit diketahui dimana keberadaan hasil uang tersebut.

Kendala yang kedua adalah Kendala Teknis yang mana kendala tersebut mengatur secara teknis dari segi pemahaman, keberanian penyidik dalam melakukan proses penyidikan dan penyelidikan, kejujuran personil penyidik/penyidik pembantu, kurangnya kualitas dari segi 
kemampuan pemahaman penyidik, kurangnya penguasaan penyidik dalam penggunaan teknologi informasi, dan sarana, prasarana, dan anggaran yang kurang untuk keperluan penyidikan tindak pidana korupsi. Dari beberapa kendala yang dihadapi maka upaya yang dilakukan pihak kepolisian dalam melakukan penyidikan tindak pidana korupsi antara lain adalah solusi daripada kendala yuridis yakni melakukan koordinasi terhadap beberapa instansi seperti operasional Polri dan koordinasi dengan Kejaksaan dan KPK, dan melakukan pemeriksaan terhadap saksi-saksi yang berkaitan agar mendapatkan informasi yang lebih akurat. Solusi untuk kendala teknis yang dihadapi penyidik kepolisian antara lain melakukan pembinaan sikap mental dan keberanian para penyidik dalam penyidikan tindak pidana korupsi, pengoptimalisasian tugas penyidik dan mendorong motivasi serta disiplin, dilakukannya pendidikan dan pelatihan untuk para penyidik terhadap penanganan tindak pidana korupsi, melakukan pelatihan teknologi informasi agar lebih paham tentang perkembangan teknologi saat ini, dan peningkatan sarana prasarana dan pengajuan anggaran. Didalam melalukan pemeriksaan tindak pidana korupsi tanpa adanya sarana atau fasilitas yang memadai, maka tidak mungkin penegak hukum akan melakukan penyidikan dengan lancar.

\section{SIMPULAN DAN SARAN}

\section{Simpulan}

Kewenangan penyidik Kepolisian dalam melakukan penyidikan tindak pidana korupsi merupakan bagian dari tugas pokok kepolisian dalam menjaga keamanan dan ketertiban di masyarakat. Ketentuan KUHAP memberikan peranan utama kepada Kepolisian Negara RI dalam penyelidikan dan penyidikan sehingga secara umum diberi kewenangan untuk melakukan penyelidikan dan penyidikan terhadap semua tindak pidana termasuk tindak pidana korupsi. Namun demikian tetap memperhatikan dan tidak mengurangi kewenangan yang dimiliki oleh penyidik lainnya seperti Kejaksaan dan Komisi Pemberantasan Korupsi sesuai dengan peraturan perundang-undangan yang menjadi dasar hukumnya masing-masing. Dalam Undang-Undang No. 2 Tahun 2002 tentang Kepolisian Negara RI bahwa penyidik Kepolisian Negara memiliki tugas dan wewenang untuk melakukan semua jenis tindak pidana termasuk melakukan penyidikan tindak pidana. Prosedur penyidikan tindak pidana korupsi yang dilakukan oleh penyidik Kepoliisian pada tahap permulaan penyidik mengumpulkan alat bukti sesuai dengan ketentuan Pasal 184 ayat 1 KUHAP setelah alat bukti tersebut terkumpul kemudian dimasukan dalam Berita Acara Pemeriksaan (BAP) dan setelah penyidikan yang dilakukan oleh penyidik Kepolisian sudah dianggap cukup maka penyidik Kepolisian menyerahkan Berita Acara Pemeriksaan tersebut kepada Penuntut Umum setelah menerima hasil penyidikan dari penyidik segera mempelajari dan menelitinya dalam waktu tujuh hari wajib memberitahukan kepada penyidik apakah hasil penyidikan itu sudah lengkap atau belum. Dalam hal hasil penyidikan ternyata belum lengkap, penuntut umum mengembalikan berkas perkara kepada penyidik disertai petunjuk tentang hal yang harus dilakukan untuk dilengkapi dan dalam waktu empat belas hari sejak tanggal penerimaan berkas, penyidik harus sudah menyampaikan kembali berkas perkara itu kepada penuntut umum. Dan hasil penyidikan tersebut tidak dikembalikan lagi oleh Penuntut Umum kepada penyidik maka penyidikan sudah dianggap cukup. Maka pada tahap pertama Berita Acara Pemeriksaan (BAP) diserahkan oleh penyidik kepada penuntut umum maka tahap yang kedua, penyidik menyerahkan tersangka dan barang bukti kepada Penuntut Umum.

\section{Saran}

Dalam rangka untuk memberantas tindak pidana korupsi di Indonesia tidak cukup peraturan perundang-undangan saja namun efek jera dan pemiskinan terhadap koruptor perlu dilakukan oleh para penegak hukum dalam menjatuhkan pidana bagi para koruptor. Mengingat belum adanya kerjasama dalam bentuk peraturan perundang-undangan antara penyidik Kepolisian dengan pihak penegak hukum lainnya seperti Kejaksaan dan KPK, maka perlu segera dibentuk undang-undang yang mengatur secara jelas dan rinci tentang kerjasama dan koordinasi dalam melakukan penyidikan tindak pidana korupsi antara penyidik Kepolisian dengan penyidik Kejaksaan dan KPK. Hal ini perlu dilakukan agar pemberantasan korupsi menjadi lebih efektif dan dapat terwujud.

\section{DAFTAR PUSTAKA}

Assa, M. I. (2017). Kewenangan Penyidik Dalam Menangani Perkara Tindak Pidana Korupsi Menurut KUHAP. Lex Et Societatis, 5(10), 71-78. 
H, B. S. (2000). Sekilas Pandang Tentang Tindak Pidana Korupsi. Fakultas Hukum Universitas Pasundan, Bandung.

Hamzah, A. (1984). Korupsi di Indonesia Masalah dan Pemecahannya. PT Gramedia Pustaka Utama, Jakarta.

Hatta, M. (2014). KPK dan Sistem Peradilan Pidana. Liberty, Yogyakarta.

Mas, M. (2014). Pemberantasan Tindak Pidana Korupsi. Ghalia Indonesia, Bogor.

Mursalim. (2017). Kewenangan Penyidik Polri dalam Penanganan Tindak Pidana Menurut Kitab Undang-undang Hukum Acara Pidana. Al-Hikam, 1(3), 19-44.

Siahaan, H. P., Marlina, \& Zul, M. (2019). Peran Kepolisian dalam Penyidikan Tindak Pidana Korupsi (Studi pada Kepolisian Daerah Sumatera Utara). ARBITER: Jurnal Ilmiah Magister Hukum, 1(2), 135-145.

Soekanto, S. (1983). Faktor-faktor yang Mempengaruhi Penegakan Hukum. Rajawali, Jakarta. 